\title{
ANALYTICAL METHODS OF CALCULATION OF POWERED AND PASSIVE TRAJECTORY OF REACTIVE AND ROCKET-ASSISTED PROJECTILES
}

Majstrenko O. V. - Dr. Sc., Chairman of department of Missile Forces Hetman Petro Sahaidachnyi National Army Academy, colonel, Lviv, Ukraine.

Prokopenko V. V. - PhD, Vice Chief of Department of Missile Forces and Artillery Scientific Center of the Army Hetman Petro Sahaidachnyi National Army Academy, colonel, Lviv, Ukraine.

Makeev V. I. - PhD, Associate Professor, Sumy State University, Military Department, Sumy, Ukraine.

Ivanyk E. G. - PhD, Associate Professor, Senior of Scientific Worker of Department of teach and training devices and military equipment, Scientific Center of the Army Hetman Petro Sahaidachnyi National Army Academy, Lviv, Ukraine.

\begin{abstract}
Context. Within the framework of the accepted simplifying hypotheses, an approximate scheme of calculation of the parameters of the active and passive sections of the trajectory is proposed, which allow to study the trajectory properties of the existing as well as perspective samples of the reactive and rocket assisted projectiles. The object of the study is a model for the calculation of the trajectories of the reactive and rocket assisted projectiles based on a nonlinear system of differential equations of motion of the center of mass of the solid.

Purpose. The purpose of the work is to propose for practical apply a new system of corrections in the range and direction for deviation of the flight conditions of the projectiles from the table value, based on the calculations of elements of the trajectory of the projectiles at the end of the active section of the trajectory, which greatly improves the accuracy of preparation of installations for firing and as a result - the effectiveness of hitting the target.

Objective. The goal of the work is to propose a new system of corrections in the range and direction for deviation of the flight conditions of the projectiles from the table value, based on the calculations of elements of the trajectory of the projectiles at the end of the active section of the trajectory, which greatly improves the accuracy of preparation of installations for firing and as a result the effectiveness of hitting the target.

Method. The proposed analytical method allows to: determine the set of indicators characterizing the process of approaching the rocket projectile from the guide and clarify the initial conditions necessary to solve the system of equations of motion on the active section of the trajectory; which is regarded as a standalone trajectory that affects the course of the projectile's flight on the active section of the trajectory. The calculation of the passive trajectory plot for rocket projectile and the second passive plot for active rockets projectile is necessary to obtain the trajectory parameters at the point of fall (in the vicinity of the target) which is important for the correction of fire in the subsequent defeat of the target by reactive (active-reactive) projectile's (mortar shells).

Results. The developed calculation method was tested in the estimation of the accuracy of the calculation of the elements of the trajectory of projectile movement.

Conclusions. The calculations performed on the basis of the developed analytical method confirm the workability of the proposed mathematical support and allow recommending it for practical use in solving problems of external ballistics with the prospect of optimizing the trajectory of motion of controlled and unmanaged flying objects. Prospects for further research are to create consistent methods for calculating tactical and technical indicators of new types of ammunition.

KEYWORDS: mathematical modeling of the ballistic solid motion, the movement of the center of masses of solids, which modeling of reactive (active-reactive) shells and mines, engine thrust, fuel flow per second, rocket fuel weight, engine run time, powered and passive trajectory sector.
\end{abstract}

ABBREVIATIONS
APT is an active powered trajectory of reactive
(rocket-assisted) shells;
PPT1 and PPT2 is the first and the second passive sec-
tor for rocket-assisted projectiles;
PTS is a passive trajectory sectors for missiles.
NOMENCLATURE
$\mathrm{C}_{x}\left(V_{\tau}\right)$ is an aerodynamic coefficient of force of fron-
tal air resistance;
$\vec{F}_{R}$ is a reactive force;
$\mathrm{F}\left(V_{\tau}\right)$ is a reference function of air drag;
$\mathrm{F}_{58}\left(V_{\tau}\right)$ is a law of air resistance;

CMajstrenko O. V., Prokopenko V. V., Makeev V. I.,Ivanyk E. G., 2020 DOI 10.15588/1607-3274-2020-2-18
$\mathrm{H}_{\tau}(Y)$ is a function of distribution of density of air along the altitude;

$I_{1}$ is a specific impulse of jet engine;

$I_{1 N}$ is a tabular values of single impulse of tractive force;

$\overrightarrow{\mathrm{N}}$ is a normal reaction of guiding line;

$\overrightarrow{\mathrm{P}}$ is a thrust force;

$\mathrm{P}_{a}$ is a pressure of powder gas;

$\mathrm{P}_{n}$ is a pressure of air on flight altitude;

$R$ is a universal gas constant;

$S_{a}$ is a sectional area;

$S_{0}$ is a quantity of the complete path of the missile on the guiding line; 
$\overrightarrow{\mathrm{T}}$ is a frictional force;

$V$ is a speed of the missile;

$Y^{\prime}$ is a height of trajectory on an area PPT1;

$W_{a x}, W_{a z}$ is a longitudinal and lateral components of the ballistic wind within the active path of the trajectory;

$a_{x}$ is an acceleration of the frontal resistance force;

$b_{1}$ is a coefficient, which can be found with the help of the table;

$c_{p}$ is a ballistic coefficient of the shell on the passive trajectory;

$d$ is a caliber of the missile;

$g$ is acceleration of gravity;

$h_{\mathrm{ON}}$ is a pressureby normal condition; tory;

$i$ is a coefficient of form of the shell on passive trajec-

$i_{a}$ is a coefficient of form of the shell on powered trajectory;

$k_{1}, k_{2}$ it's a dimensional coefficients that take into account the effect of jet charge temperature on a single thrust pulse and jet engine operating time;

$m_{0}$ is an initial mass of the missile;

$m_{\mathrm{T}}$ is a mass of solid fuel;

$q_{a}$ is a actual weight of the missile;

$t$ is a flight time of the shell;

$t_{0}$ is a descent initial time of the missile from the

guiding line;

$t_{1}$ is a descent final time of the missile from the guiding line;

$t_{\text {work }}$ is a engine turn-on time;

$v_{0}$ is a descent speed of the missile from guiding line;

$w$ is a acceleration of the is acceleration of the center of mass of the missile;

$\vec{w}_{a}$ is an efflux speed;

$\gamma$ is a wind coefficient;

$\mu_{0}$ is a ratable part of powder charge;

$\theta$ is a bend touch angle to trajectory;

$\theta_{0}$ is a elevation angle;

$\tau$ is a virtual temperature;

$\tau_{a}$ is a jet engine run time;

$\tau_{a \mathrm{~N}}$ is a tabular values of time of work of engine for the tabular value of temperature of reactive fighting $\operatorname{load} T_{\text {fload }}=15^{\circ} \mathrm{C}$;

$\tau_{\mathrm{ON}}$ is a temperature by normal condition.

\section{INTRODUCTION}

The calculation of the parameters of powered and passive trajectory is important ballistic task [1-6]. Approximate scheme methods are needed to calculate the parameters of powered and passive trajectory sectors, required to get the sectors of trajectory in arbitrary point, also to search the characteristics of new model missile's trajectory.

The object of study is a model for the calculation of the trajectories of the reactive and rocket assisted projectiles based on a nonlinear system of differential equations of motion of the center of mass of the solid.

The subject of study is the sampling methods used in an approximate scheme of calculation of the parameters of the active and passive sections of the trajectory in reactive and rocket assisted projectiles.

The purpose of the work is a new system of corrections in the range and direction for deviation of the flight conditions of the projectiles from the table value, based on the calculations of elements of the trajectory of the projectiles at the end of the active section of the trajectory, which greatly improves the accuracy of preparation of installations for firing and as a result - the effectiveness of hitting the target.

\section{PROBLEM STATEMENT}

In the first step we provide calculation of descent parameters of the missile from the guiding line. There is no method of determination of descent parameters of the missile from the guiding line in exterior ballistic literature $[1,2,4-6]$.

To solve the set of the system of differential equations of movement of reactive (rocket-assisted) projectile on trajectory it's necessary to know the initial conditions: descent speed of the missile from guiding line $-v_{0}$; descent time $-t_{0}$, ratable part of powder charge $\mu_{0}$ is burnt till the descent moment.

Let's consider the movement of the missile along the guiding line with next suppositions.

1. The missile executes only a motion of translation under the thrust force $\mathrm{P}$, gravity $G_{0}=m_{0} g$ and frictional force $\mathrm{T}$ of master devices of the shell, along the guiding line (Fig. 1).

2. With low movement speed of the missile along the guiding line the drag force is very low, consequently it is not taken into account.

The methodology, described in this chapter, allows calculating descent parameters of the missile from the guiding line, which are necessary to solve the system of differential equations of movement of the missile on powered trajectory.

Further we make the calculation of powered trajectory of reactive (rocket-assisted) shells.

Next step - the calculation of the passive trajectory sector of the missiles and rocket-assisted projectiles.

Therefore, the calculation of the parameters of the active section of the trajectory is carried out on the basis of a mathematical model consisting of an appropriate system of differential equations, which we denote as $\left\langle S_{d}^{A P T}\right\rangle$, and, respectively, given the initial conditions for reactive and rocket-assisted projectiles. The main problem in finding the parameters of the active section of the trajectory - 
the determination of the relative current leakage of gases, with the initial conditions must be relevant data taken from the firing tables, as well as values due to meteorological factors.

The calculation of the second passive section of the trajectory of the projectile flight will be carried out on the basis of a correspondingly adapted mathematical model $\left\langle S_{d}^{P P T_{2}}\right\rangle$ and the assumption of speed constancy at the beginning of the considered section of the trajectory. At this stage, the task is to determine the horizontal component and the motion time of the projectile in the final section of the trajectory.

\section{REVIEW OF THE LITERATURE}

Nowadays, during the studying of flight of reactive and rocket-assisted projectiles, very important task is studying of powered and passive trajectory parameters. In general, amount of mistakes in firing preparation on powered trajectory comes up to $60-70 \%$ of total amount of mistakes [8].

There is no simple analytical dependences in modern ballistic literature $[1,2,6]$, which allow to calculate in the first approximation parameters of powered and passive trajectory and in cut-off engine point. These mathematical dependences can be used for previous assessment of characteristics of developed type of the shell.

In the paper [9] describes a new multidisciplinary computational study undertaken to model the flight trajectories and the free-flight aerodynamics of both a finned projectile at supersonic velocities and a spinning projectile at subsonic speeds with and without aerodynamic flow-control. A method to efficiently generate a complete aerodynamic description for projectile flight dynamic modelling is described in work [10]. In a train aid [11] basic information is expounded about motion of rockets in space, resulted equalizations of motion of aircraft for the active and passive areas of trajectory. In the works $[3,12]$ is offered model of the moving, the flying machine on solid fuels with account for rotation and curvatures of the Earth, influences wind and other aerodynamically parameter's; the research of the works parameters influence of ramjet on distance and precisions of jet-projectiles is conducted in paper [13].

A realistic non-linear flight dynamics model has been developed to perform simulations to prove the accuracy of the presented algorithms [14]. The work [15] address a full six degrees of freedom projectiles flight dynamics analysis. In the paper [16] introduces a novel approach for controlling the exterior ballistic properties of spinstabilized bullets by optimizing their internal mass distributions.

Currently, mathematical models to study external ballistics are cumbersome. This work aims to define and expand upon the theoretical procedure of determination of complex of indexes which accompany motion of different flying objects.

\section{MATERIALS AND METHODS}

To solve this problem, the basic relations and equations of the external ballistics, describing the movement of the center of masses of reactive (active-reactive) shells and mines, are taken into account, taking into account the forces acting on the moving object of external forces and moments. Analytical solutions are based on the use of the small correction method and the linearization of the corresponding aerodynamic and kinematics characteristics. To determine the elements of the motion of the jet projectile at the key moments of motion (climbing from the guide), at the end of the active site and the passive section of the trajectory, take the averaged values of the force of traction and mass of the projectile during the movement on the specified areas, and also used tables of external ballistics or the classical method of Siacci.

Let's make up an equation of translational motion of the missile along the guiding line, with elevation angle $\theta_{0}$ (Fig. 1):

$$
m_{0} w=\mathrm{P}-G_{0} \sin \theta_{0}-\mathrm{T} .
$$

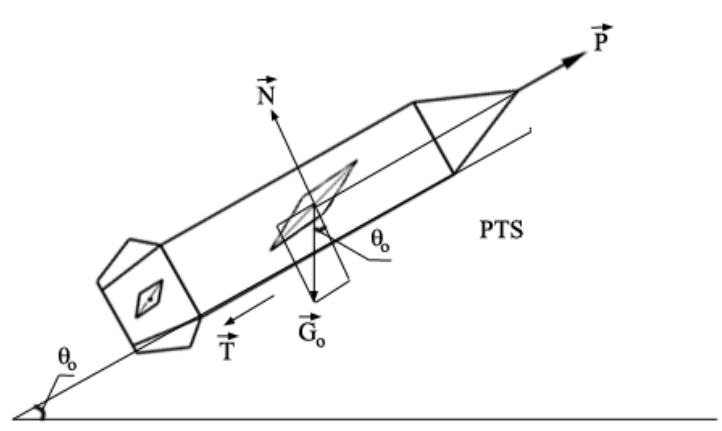

Figure 1 - The movement of the missile along the guiding line

The frictional force $\mathrm{T}=f N$ in formulae (1) is product of the coefficient of frictional force $f$ to normal reaction of guiding line $\mathrm{N}$, which we will determine from balance of forces on perpendicular to guiding line:

$$
N-\mathrm{G}_{0} \cos \theta_{0}=0 \text { or } N=\mathrm{G}_{0} \cos \theta_{0} .
$$

Adding to equation (2) the amount of frictional force $\mathrm{T}=f \mathrm{~N}=f \mathrm{G}_{0} \cos \theta_{0}, \mathrm{G}_{0}=m_{0} g$, we will determine the translator's acceleration of the shell on the guiding line:

$$
w=\frac{\mathrm{P}}{m_{0}}-g\left(\sin \theta_{0}+f \cos \theta_{0}\right) .
$$

In general, with changeable quantities of mass of the shell $\mathrm{m}$ and engine thrust force $\mathrm{P}$ we will determine the speed $v$ and the path $S_{0}$ of the missile on the guiding line using the method of tabular integration of the equation (3), using the ratio of acceleration $w$, speed $v$ and the path $S_{0}$ : 


$$
v=\int_{0}^{t} w d t, S_{0}=\int_{0}^{t} v d t
$$

For approximate calculation of the elements of movement of the missile in the moment of descent from the guiding line, permanent and averaged values of thrust force $\mathrm{P}$ and mass of the shell are taken. In this case it's reasonable to consider that the movement of the missile on the guiding line has permanent acceleration

$$
j=\frac{\mathrm{P}_{a v}}{m_{a v}}-g\left(\sin \theta_{0}+f \cos \theta_{0}\right) .
$$

Consider with $|\dot{m}|=$ const $=\frac{\omega_{0}}{\tau_{a}}$, where $|\dot{m}|$ is expense of fuel per second, that $\mathrm{P}_{a v}=U_{e}(\dot{m})=U_{e} \frac{\omega_{0}}{g \tau_{a}}$ and $m_{a v} \approx m_{0}$, we will get estimated expression of permanent (average) acceleration of the missile on the guiding line:

$$
j=\frac{U_{e} \omega_{0}}{g \tau_{a}}-g\left(\sin \theta_{0}+f \cos \theta_{0}\right) .
$$

Using the formulas of uniformly accelerated movement, we will determine the speed $v_{0}$ and time $t_{0}$ of the descent of the missile from the guiding line:

$$
v_{0}=\sqrt{2 j S_{0}}, t_{0}=\sqrt{\frac{2 S_{0}}{j}} .
$$

If $t_{0}$ is known, then we will determine a ratable part of the powder fighting load $\mu_{0}$, which had been burnt till the descent moment:

$$
\mu_{0}=\frac{|\dot{m}| t_{0}}{m_{0}}=\frac{\omega_{0} t_{0}}{q_{a} \tau_{a}} .
$$

The quantity $\mu_{0}$ is needed to calculate elements of powered trajectory of the missile.

Consequently, the parameters of the descent of the missile from the guiding line $v_{0}, t_{0}, \mu_{0}$ can be used as initial conditions to solve the set of equations of movement of the missile along passive and powered trajectory in account to data from Table 1 .

Using dependences [3, 4, 6-8] have been determined descent parameters of the missile from the guiding line: $v_{0}=39.5 \mathrm{~m} / \mathrm{s}, t_{0}=0.1748 \mathrm{~s}, \mu_{0}=0.0157$.

CMajstrenko O. V., Prokopenko V. V., Makeev V. I.,Ivanyk E. G., 2020 DOI 10.15588/1607-3274-2020-2-18
Table 1 - The example of calculation of parameters of descent of the missile from the guiding line

\begin{tabular}{|l|l|}
\hline \multicolumn{2}{|c|}{ Initial data } \\
\hline Caliber of the missile & $d=0.182 \mathrm{~m}$ \\
\hline Full initial weight of the missile & $q_{0}=160 \mathrm{~kg}$ \\
\hline Weight of reactive (powder) fighting load & $\omega_{0}=42.5 \mathrm{~kg}$ \\
\hline $\begin{array}{l}\text { Thruster-on time (total burning time of the } \\
\text { powder fighting load) }\end{array}$ & $\tau_{a}=2.96 \mathrm{~s}$ \\
\hline Effective velocity of powder gas & $U_{e}=2020 \mathrm{~m} / \mathrm{s}$ \\
\hline $\begin{array}{l}\text { Form coefficient of the missile according to } \\
\text { reference function of air drag 1943rd year }\end{array}$ & $i_{43}=1.4$ \\
\hline Elevation angle & $\theta_{0}=40^{0}$ \\
\hline $\begin{array}{l}\text { Path length of the missile along the guiding } \\
\text { line }\end{array}$ & $S_{0}=2.66 \mathrm{~m}$ \\
\hline Friction coefficient is accepted & $f=0.1$ \\
\hline
\end{tabular}

These findings correlate very accurately with calculations conducted by modeling of equation system of movement of the missile along the guiding line [4].

Reactive (rocket-assisted) shell has a reactive engine, it creates reactive force $\vec{F}_{R}$ (Fig. 2).

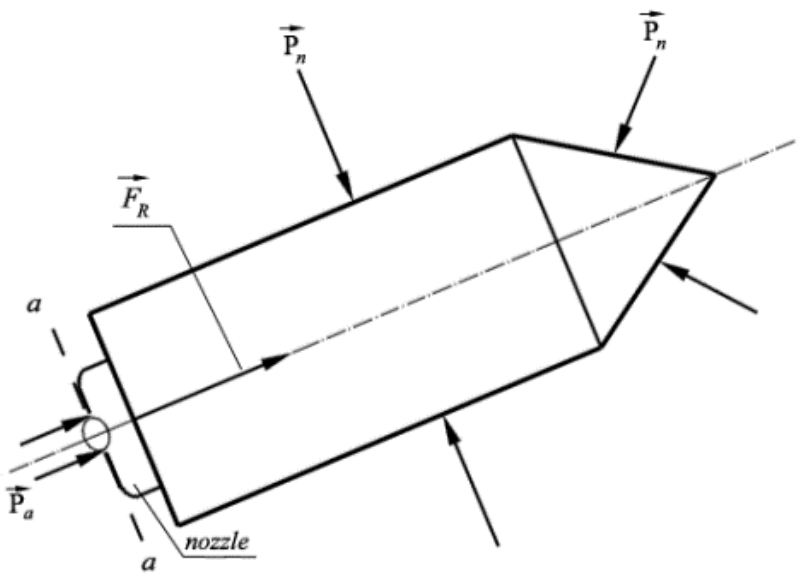

Figure 2 - Acting of reactive force $\vec{F}_{R}$

Reactive force is a result of powder gas efflux through a nozzle with efflux speed $\vec{w}_{a}$, which amount for solid fuel reactive engine is about 2000 meters per second. The second important characteristic of efflux process is a massive gas flow rate through the nozzle: $\dot{m}=\left|\frac{d m}{d t}\right|$. The mass of the missile with running engine on powered trajectory will be changeable because of gas efflux, i.e. $m=m(t)$. In nozzle exit section $a-a$, which sectional area is $S_{a}$, pressure of powder gas $\mathrm{P}_{a}$ can run up to 1.0..1.5 MPa. Reactive force vector $\vec{F}_{R}$ is directed to the side, which is reversed to flow speed vector $\vec{U}_{a}$. The amount of reactive speed $F_{R}$ is the product of second flow and gas efflux speed $U_{a}$ :

$$
F_{R}=|\dot{m}| U_{a}
$$


Naturally, reactive force is resultant of all the pressure forces, which affect the interior surface of jet engine. Thus, resultant pressure force to the direction of reactive force $S_{a}\left(\mathrm{P}_{a}-\mathrm{P}_{n}\right)$ will affect the external surface of the missile, including the area of nozzle exit section $S_{a}$. The sum of reactive force and that additional pressure force makes up engine thrust $P$ :

$$
\mathrm{P}=|\dot{m}| U_{a}+S_{a}\left(\mathrm{P}_{a}-\mathrm{P}_{n}\right) .
$$

The first item in formula (10) is the main and known as dynamic component of thrust; the second one for missiles composes $10 \ldots 15 \%$ of the first [4] and is known as static component of thrust. If to factor out the main item and bring to a close the designation:

$$
U_{e}=U_{a}\left[1+\frac{S_{a}\left(\mathrm{P}_{a}-\mathrm{P}_{n}\right)}{\dot{m} U_{a}}\right]
$$

then, we will get a new clause for thrust force:

$$
\mathrm{P}=|\dot{m}| U_{e} .
$$

The engine power setting missile changes lowly, consequently we can regard the flow speed $U_{e}$ as constant, and the flow per second $\dot{m}$ and pressure $\mathrm{P}_{a}$ are changing pro rata to the pressure inside the engine chamber. Therefore, thrust power of the missile is regarded as constant and equal:

$$
\mathrm{P}=\dot{m} g I_{1},
$$

where $I_{1}$ is value, which will be determined according to formula [2].

So, the specific impulse of jet engine being the relation of complete impulse of tractive $I$ force in times of work of engine to weight of reactive charge force is important description of efficiency of gunpowder ramjet $\omega$ :

$$
I_{1}=\frac{I}{\omega}=\frac{\int_{0}^{\tau_{a}} P d t}{\omega} .
$$

Making necessary transformations of dependence (13) finally we come to the formula for the specific impulse of jet engine

$$
I_{1}=\frac{\dot{m} U_{e} \tau_{a}}{m_{\mathrm{T}} g} .
$$

If only one thrust force $\mathrm{P}$ influences on the shell, then we will get a clause for deliberate speed of shell's headway $V_{\max }$ :

CMajstrenko O. V., Prokopenko V. V., Makeev V. I.,Ivanyk E. G., 2020 DOI 10.15588/1607-3274-2020-2-18

$$
V_{\max }=U_{e} \ln \left(1+m_{\mathrm{T}} / m_{P}\right),
$$

where $m_{P}=m_{0}-m_{\mathrm{T}}-$ is passive mass of the shell on passive part of trajectory.

Missile trajectory (Fig. 3) consists of powered trajectory sector from take-off point $\mathrm{O}$ to the point $\mathrm{K}$, where burning of solid fuel ends, and two sectors of passive trajectory: passive trajectory sector 1 from point $K$ to point $C^{\prime}$, it's ordinate is equal to ordinate $Y_{k}$, and passive trajectory sector 2 from point $C^{\prime}$ to the incidence point $C$. Rocket-assisted projectile trajectory has one more passive trajectory sector from take-off point to engine ignition point $\mathrm{F}$ where subsides inflammation of solid fuel and powered trajectory sector starts from point $\mathrm{F}$ to engine cut-off point $\mathrm{K}$. The second passive trajectory sector for rocket-assisted projectile includes passive trajectory sector 1 and passive trajectory sector 2 - for a missile.

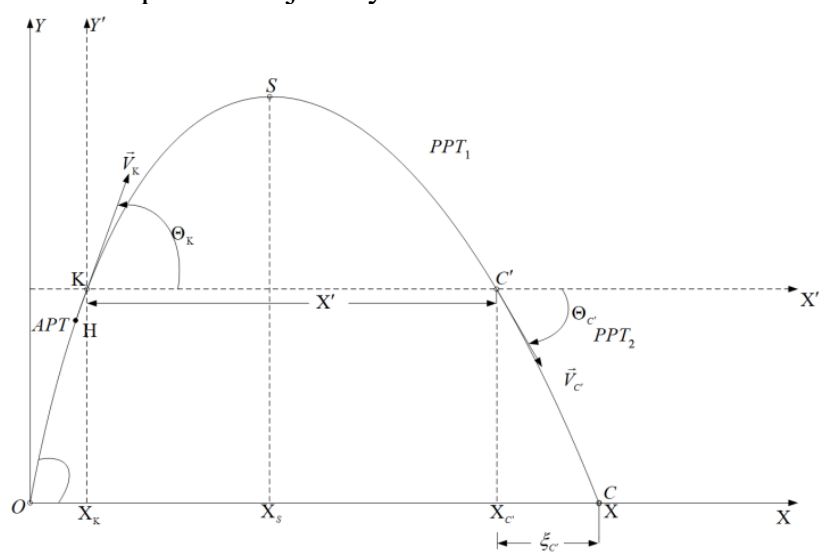

Figure 3 - The trajectory of the reactive (rocket-assisted) projectile

To calculate powered trajectory sector we will use set of equations for shell's headway in the trajectory frame of axis influenced

$$
\begin{gathered}
\dot{V}=\frac{\mathrm{P}-R_{\mathrm{T}}}{m}-g \sin \theta ; \dot{\theta}=-\frac{g \sin \theta}{V} ; \\
\dot{X}=V \cos \theta ; \dot{Y}=V \sin \theta,
\end{gathered}
$$

by three forces: gravitation $\mathrm{G}=m g$; drag force $R_{\mathrm{T}}=i_{a} d^{2} 10^{3} \mathrm{H}_{\tau}(Y) \mathrm{F}\left(V_{\tau}\right) V$ and thrust force $\mathrm{P}=\dot{m} U_{e}[1$, 2], $V_{\tau}=V \sqrt{\frac{\tau_{\mathrm{ON}}}{\tau}}$ - conventional table speed.

The coefficient of form of the shell $i_{a}$ on powered trajectory will be minor than on passive: $i_{a} \cong 0.75 i$. Changeable mass of reactive (rocket-assisted) projectile $m$ is expressed by formula:

$$
m=m_{0}-\int_{0}^{t}|\dot{m}| d t .
$$

According to exterior ballistic, reactive (rocketassisted) projectile trajectory is flat, but it's azimuth de- 
viation during all the movement time amounts to zero: $z=0$.

Let's input a new variable $\mu-$ it's ratable gas flowing

$$
\mu=\int_{0}^{t} \frac{|\dot{m}|}{m_{0}} d t
$$

it changes from 0 to $\mu_{k}=m_{\mathrm{T}} / m_{0}$ in the moment $t=t_{k}$. Then formula (17) will be:

$$
m=m_{0}(1-\mu)
$$

Let's derive the equation (18) to $t \frac{d \mu}{d t}=\frac{\dot{m}}{m_{0}}$, whence

$$
\frac{d t}{d \mu}=\frac{m_{0}}{\dot{m}}, k=\frac{m_{0}}{\dot{m}} \text { then } d t=k d \mu
$$

Using the last proportion we will pass from argument $t$ to argument $\mu$ in equations (16) and considering information in work [3] we will get the system of differential equations of movement of reactive (rocket-assisted) projectile on trajectory:

$$
\left\{\begin{array}{c}
\dot{X}=V_{r} \cos \theta \cos \psi \\
\dot{Y}=V_{r} \sin \theta \\
\dot{Z}=V_{r} \cos \theta \sin \psi \\
\dot{V}=a(t)-a_{x} \cos \gamma-g \sin \theta \\
\dot{\theta}=-g \frac{\cos \theta}{V_{r}}-\frac{a_{x} W_{a x} \sin \theta \cos \gamma}{V_{r}^{2}} \\
\dot{\psi}=-\frac{a_{x} W_{a z} \cos \gamma}{V_{r}^{2} \cos \theta} \\
\dot{\pi}(Y)=-\frac{\pi(Y) \dot{Y}}{R \tau(Y)}
\end{array}\right.
$$

where

$$
\begin{aligned}
& a(t)=\frac{\omega_{0}\left(\mathrm{I}_{1 \mathrm{~N}}+k_{1} \Delta T_{\text {fload }}\right)}{m_{0}\left(\tau_{a \mathrm{~N}}+k_{2} \Delta T_{\text {fload }}\right)\left(1-\mu_{y}\right)} ; \\
& \mu_{y}=\frac{\omega_{0}\left(t-t_{\text {work }}\right)}{m_{0}\left(\tau_{a \mathrm{~N}}+k_{2} \Delta T_{\text {fload }}\right)} ; \quad \Delta T_{\text {fload }}=T_{\text {fload }}-15^{\mathrm{o}} \mathrm{C} ; \\
& \pi(Y)=\frac{h}{h_{\mathrm{ON}}} ; \quad h=h_{\mathrm{ON}} e^{-\frac{1}{R} \int_{0}^{Y} \frac{d y}{\tau(y)}}-\quad \text { pressure; } \\
& V_{r}=V \sqrt{1-\frac{2\left(W_{a x} \cos \theta \cos \psi+W_{a z} \sin \psi \cos \theta\right)}{V}+\frac{W_{a}^{2}}{V^{2}}},
\end{aligned}
$$

where $W_{a}^{2}=W_{a x}^{2}+W_{a z}^{2}$. All signs are well known in exterior ballistics $[1,2,5]$.

For aircrafts, stabilized by empennage:

CMajstrenko O. V., Prokopenko V. V., Makeev V. I.,Ivanyk E. G., 2020 DOI 10.15588/1607-3274-2020-2-18

$$
a_{x}=\frac{i d^{2}}{q_{a}} 10^{3} \pi(\mathrm{Y}) \frac{F_{58}\left(V_{r \tau}\right)}{1-\mu_{\gamma}}
$$

for aircrafts, stabilized by rotation:

$$
\begin{gathered}
a_{x}=0.474 \frac{i d^{2}}{q_{a}} \pi(\mathrm{Y}) V_{r \tau}^{2} C_{x}\left(V_{r \tau}\right) ; \cos \gamma=\frac{V-W_{a x} \cos \theta}{V_{r}} ; \\
V_{r \tau}=V_{r} \sqrt{\frac{\tau_{\mathrm{ON}}}{\tau}}
\end{gathered}
$$

moreover in this case are $\mu_{\gamma}=\frac{\omega_{0} t}{q_{0} \tau_{a}}$.

Initial conditions, in which set of equations (21), should be solved are $\mu=0$ : for a missile $X=0, Y=0$, $V=0, \quad \theta=\theta_{0}, \quad t=0$; for rocket-assisted projectile $X=X_{1} ; Y=Y_{1} ; V=V_{1} ; \theta=\theta_{1} ; t=t_{1}$.

\section{EXPERIMENTS}

The system (21) consists of five equations, contains five desired quantities $X, Y, V, \theta, t$ and, consequently it is complete. The first three equations are combined, they should be solved in conjunction. The last equations don't allow to find the dependence between $t$ and $\mu$. If gas flow rate per second $\dot{m}$ is constant average value $\dot{m}=m_{\mathrm{T}} / t_{k}$, then values $c_{a}$ and $k$ is constant also. In this case, the dependence between $t$ and $\mu$ will be clear: for a missile $t=k \mu$; for rocket-assisted projectile $t=k \mu+t_{1}$.

Elements of a trajectory in the end of active sector $X_{k}, Y_{k}, Z_{k}, V_{k}, \theta_{k}$ arm determined under the condition that $t=t_{k}\left(t=t_{k}+t_{1}\right)$ or $\mu=\mu_{k}$. So, it's necessary to integrate the set of equations (21) or to solve the system of equations (16) with the help of exterior ballistic tables $[2,7]$.

If we calculate the trajectory parameters in cut-off engine point according to table conditions: $V_{k}^{\mathrm{T}}, \theta_{k}^{\mathrm{T}}, X_{k}^{\mathrm{T}}$, $Y_{k}^{\mathrm{T}}$ and real conditions: $V_{k}^{p}, \theta_{k}^{p}, X_{k}^{p}, Y_{k}^{p}, Z_{k}^{p}$ a new deductions system con be offered, which lies in calculation of deductions for powered trajectory for divergences from tabular firing conditions: range $\Delta \mathrm{X}=\mathrm{X}_{k}^{p}-\mathrm{X}_{k}^{\mathrm{T}}$ speed $\Delta V=V_{k}^{p}-V_{k}^{\mathrm{T}}$, angle of elevation $\Delta \theta=\theta_{k}^{p}-\theta_{k}^{\mathrm{T}}$, altitude of trajectory $\Delta \mathrm{Y}=\mathrm{Y}_{k}^{p}-\mathrm{Y}_{k}^{\mathrm{T}}$ and side direction $\Delta \mathrm{Z}=\mathrm{Z}_{k}^{p}-\mathrm{Z}_{k}^{\mathrm{T}}$.

\section{RESULTS}

Thus:

1. The system of recording of deductions, described in this chapter, which lies in calculation of deviation of parameters of the trajectory in the end of powered sector 
from table, allows improving accuracy of determination of purposes for reactive artillery firing.

2. The accuracy of determination of firing purposes on the base of full artillery preparation by the present method, according to the correction columns of The firing tables is $1.5-2 \%$ in range and $5-10$ points of a protractor in direction [7], and by described method, as calculations have shown, $0.9-1.2 \%$ in range and $3-5$ points of a protractor in direction [3].

The first passive sector may be considered as independent trajectory, which has initial speed $V_{k}$ and the angle of departure $\theta_{k}$, therefore, the calculation of passive trajectory sector probably doesn't differ from calculation of shell trajectory by the methods, described earlier $[1,2,5]$. Besides it, we should take into account the next peculiarities: the mass of the shell will be equal to passive mass $m_{p}$; the crest factor $i_{n}$ of the missile with cut-off jet engine after solid fuel is burnt, should be determined; the density of air in departure point $\mathrm{K}$ and dispensing of air along the height differ from normal. The next case we can take into account using the next ballistic coefficient $c^{*}[2]:$

$$
\begin{gathered}
c^{*}=c_{p}\left[b_{1} H\left(Y_{k}\right)+0.53 \frac{H\left(Y_{k}+Y^{\prime}\right)}{H\left(Y^{\prime}\right)}\right], \\
c_{p}=\frac{i_{p} d^{2} 10^{2}}{m_{p}},
\end{gathered}
$$

$b_{1}-$ is the coefficient, which can be found with the help of the Table 2 account to [2]:

Table 2 - The fragment of found of the coefficient of the shell

\begin{tabular}{|l|c|c|c|c|c|}
\hline$c_{p}$ & 0.20 & 0.30 & 0.40 & 0.60 & 0.80 \\
\hline$b_{1}$ & 0.435 & 0.450 & 0.465 & 0.475 & 0.480 \\
\hline
\end{tabular}

In the first approximation, before we get the quantity $Y^{\prime}$, we take the ballistic coefficient $c^{*}=c_{p} \mathrm{H}\left(Y_{k}\right)$, then we refine it according to the dependence (22) and, eventually, we can determine the trajectory sectors in the point $C^{\prime}: X^{\prime}, T^{\prime}, V_{C^{\prime}}, \theta_{C^{\prime}}$ according to the exterior ballistic tables $[2,6]$.

The second passive trajectory sector can be calculated with different approximation extent. The first approximation can be considered as linear, which creates with axis abscissa $\theta_{c}^{\prime}$, and the translational motion of the missile as equal to the speed $V_{C^{\prime}}$. In the first approximation we will get clear clauses of the horizontal movement $\xi_{c}$ and time of movement $\tau_{c}$ of the shell on the second passive sector:

CMajstrenko O. V., Prokopenko V. V., Makeev V. I.,Ivanyk E. G., 2020 DOI 10.15588/1607-3274-2020-2-18

$$
\xi_{c, 1}=\frac{Y}{\operatorname{tg}\left|\theta_{C^{\prime}}\right|}, \tau_{c, 1}=\frac{Y_{k}}{V_{C^{\prime}} \sin \left|\theta_{C^{\prime}}\right|}
$$

and the elements of the trajectory in the incidence point $C$ :

$$
\begin{gathered}
X=X_{k}+X^{\prime}+\xi_{c, 1}, \mathrm{~T}=t_{k}+\mathrm{T}^{\prime}+\tau_{c, 1}, \\
\theta_{C}=\theta_{C^{\prime}}, V_{C}=V_{C^{\prime}} .
\end{gathered}
$$

The last two equations are acceptable for practice, but for the first two it's necessary to refine the quantities $\xi_{c}$ and $\tau_{c}$, using expansion of the ordinate $Y$ in a row in environs of the point $C^{\prime}$ according to quantity degree $\xi=X-X_{C^{\prime}}$ and $\tau=t-t_{C^{\prime}}$. Finally we will get:

$$
\xi_{c}=\xi_{c, 1}-\mathrm{A}_{2} \xi_{c, 1}^{2}-\mathrm{A}_{3} \xi_{c, 1}^{3}, \tau_{c}=\tau_{c, 1}-\mathrm{B} \tau_{c, 1}^{2}
$$

where

$$
\begin{aligned}
& \mathrm{A}_{2}=\frac{g}{2 V_{C^{\prime}}^{2} \cos ^{2} \theta_{C^{\prime}} \operatorname{tg}\left|\theta_{C^{\prime}}\right|} ; \quad \mathrm{A}_{3}=\frac{c_{p} \mathrm{H}\left(Y_{k}\right) \mathrm{F}\left(V_{C^{\prime}}\right) g}{3 V_{C^{\prime}}^{3} \cos ^{3} \theta_{C^{\prime}} \operatorname{tg}\left|\theta_{C^{\prime}}\right|} ; \\
& \mathrm{B}=\frac{g-c_{p} \mathrm{H}\left(Y_{k}\right) \mathrm{F}\left(V_{C^{\prime}}\right) V_{C^{\prime}} \sin \left|\theta_{C^{\prime}}\right|}{2 V_{C^{\prime}} \sin \left|\theta_{C^{\prime}}\right|} .
\end{aligned}
$$

Consequently, by explaining and clarifying an analyzed method of calculating for the description of shells and mines in motion and examining the important practical problems related to indexes, we clarify and indicate that these concepts influence both the theoretical picture for development of reliable analytical methods and suggest important practical problems related to the calculation of tactical and technical indexes of jet-projectiles. They form the theoretical basis of modern strategy for creation of new types of live ammunitions.

\section{DISCUSSION}

The calculation of the passive trajectory sector (from point $\mathrm{O}$ to point $\mathrm{N}$ ) for rocket-assisted projectile is the simple calculation of the elements of the trajectory in random point; this calculation is made with the help of the exterior ballistic tables [2,6] or with Siacci method [6]. The system of equations (21) can be used for accurate calculation of trajectory elements.

Thus, dependences of calculation of passive trajectory, with the help of exterior ballistic tables, allow to assess approximately parameters of trajectory in the missile impact point, aimed to assess previously the quality of the ammunition on development stage; mistakes in determination of parameters of passive trajectory, according to tables of exterior ballistic $[2,6]$ and with the help of the system of differential equations (21), as calculations have shown, come to $7-10 \%$ [3].

\section{CONCLUSIONS}

1. In this article are offered analytic dependences for calculation of the parameters of the descent of the missile from the guiding line, which are the initial conditions to 
solve the set of equations of the movement on active and passive trajectory sectors.

2. Here is offered the set of equations of the movement of the reactive (rocket-assisted) shell, which allows calculating it's parameters in the end of the powered trajectory, what underlies new way of the determination of the devices for those type of shell. As calculations have shown the accuracy of determination of purposes for firing by offered method comes to $0.9-1.2 \% 0,9-1,2 \%$ in range, and 3-5 points of a protractor in direction, by the modern method $-1.5-1.2 \%$ in range and 5-10 points of a protractor in direction.

3. The analytic methods of the calculation of active and passive trajectory sectors of the aircrafts allow determining what factors and how influencing on the flight parameters, what can be taken into account during the development of the new, perspective models of reactive (rocket-assisted) shells.

The scientific novelty. The analytical methods of determination of parameters of descend reactive and rocket assisted projectiles are developed from sending, that suitable for the use at establishment of closer definition of initial conditions in the process of solution of the system of nonlinear differential equations of motion on the active and passive area of trajectory.

The practical significance of obtained results is: the analytical methods of calculation of active and passive areas of trajectory of motion of reactive and rocket assisted projectiles offered in the article allow preliminary to estimate, what factors and in what measure influence on the kinematics parameters of their flight and also will allow to take into account in technical calculations on the stage of development of perspective standards of and jetprojectiles.

Prospects for further research are: research of influencing of passive area of trajectory of motion of reactive projectiles and second passive area of motion of rocket assisted projectiles enables to determine the parameters of trajectory in the point of falling (neighborhoods of target) that is important for a correction fire at firings and also at the fire inflicting defeat of destroying target during the next starting of shells.to study the proposed set of indicators for a broad class of practical problems.

\section{REFERENCES}

1. Dmitrievskij A. A., Lysenko L. N. External ballistics. Moscow, Engineering, 2005, 607 p.

2. Gantmakher F. R., Levin L. M. The flight of uncontrolled rockets. New York, Pergamum Press, 1964, 379 p.

3. Makyeyev V. I. Mathematical model spatial movement aircraft solid fuel in the atmosphere, Messenger Sumy State University, 2008, No. 2, pp. 5-12.
4. Abbas L. K., Rui X. Numerical investigations of aero elastic divergence parameter of unguided launch vehicles, Space Research Journal, 2011, Issue 4(1), pp. 1-11. DOI: 10.3923/srj.2011.1.11

5. Burlov V. V., Lysenko L. N. Ballistics receiver systems Moscow, Engineering, 2006, 459 p.

6. Morote J., Liaño G. Flight Dynamics of Unguided Rockets with Free-Rolling Wrap Around Tail Fins, Journal of Spacecraft and Rockets, 2006, Issue 43(6), pp. 1422-1423. DOI: $10.2514 / 1.22645$

7. Sun H., Yu J., Zhang S. The control of asymmetric rolling missiles based on improved trajectory linearization control method, Journal of Aerospace Technology and Management, 2016, Vol. 8, No. 3, pp. 319-327. DOI: 10.5028/jactm.v813.617

8. Arutyunova N. K., Dulliev A. M., Zabotin V. I. Models and methods for three external ballistics inverse problems, Bulletin of the South Ural State University. Ser. Mathematical Modelling, Programming \& Computer Software (Bulletin SUSU MMCS), 2017, Vol. 10, No. 4, pp. 78-91. DOI: $10.14529 / \mathrm{mmp} 170408$

9. Sahu J. Unsteady computational fluid dynamics modeling of free-flight projectile aerodynamics, WITTransactions on Modelling and Simulation, 2007, Vol. 45, pp. 3-12. DOI: 10.2495/CBAL070011

10. Kokes J., Costello M., Sahu J. Generating an aerodynamic model for projectile flight simulation using unsteady time accurate computational fluid dynamic results, WIT Transactions on Modelling and Simulation, 2007, Vol. 45, pp. 3154. DOI: 10.2495/CBAL070041

11. McCoy R. L. Modern Exterior Ballistics: The Launch and Flight Dynamics of Symmetric Projectiles. Atglen, PA, Schiffer Publishing Ltd., 2012, 328 p.

12. Makeev V. I. Grabchak V. I., Trofimenko P. E., Pushkarev Y. I. Research of jet engine operation parameters on the range and accuracy of firing of rockets, Information processing system, 2008, Vol. 6(73), pp. 77-81.

13. Grabchak V. I., Makeev V. I., Trofimenko P. E., Pushkarev $\mathrm{Yu}$. I Substantiation of a rational correction system for firing with active rockets (mines), Artillery and small arms, 2009. No. 4, pp. 3-9.

14. Celis R. D., Cadarso L., Sánchez J. Guidance and control for high dynamic rotating artillery rockets, Aerospace Science and Technology, 2017, Vol. 64, pp. 204-212. DOI:10.1016/j.ast. 2017.01.026

15. Gkritzapis D. N., Kaimakamis G., Siassiakos K., Chalikias M. A review of flight dynamics simulation model of missiles, $2^{\text {nd }}$ European Computing Conference (ECC'08). Malta, September 11-13, 2008, pp. 257-261.

16. Lahti J., Sailaranta T., Harju M., Virtanen K. Control of exterior ballistic properties of spin-stabilized bullet by optimizing internal mass distribution, Defense Technology. 2019, Vol. 15, pp. 38-50. DOI: 10.1016/j.dt.2018.10.003Received 00.00.2020.

Received 25.02.2020. Accepted 15.04.2020.

УДК 629.072 .19

\section{АНАЛІТИЧНІ МЕТОДИ РОЗРАХУНКУ АКТИВНОЇ І ПАСИВНОЇ ДІЛЯНОК ТРАЄКТОРІЇ РЕАКТИВНИХ І АКТИВНО-РЕАКТИВНИХ СНАРЯДІВ}

Майстренко О. В. - д-р військових наук, начальник кафедри ракетних військ Національної академії сухопутних військ імені гетьмана Петра Сагайдачного, полковник, Львів, Україна. 
Прокопенко В. В. - канд. техн. наук, заступник начальника науково-дослідного відділу (ракетних військ та артилерії) Наукового центру Сухопутних військ Національної академії сухопутних військ імені гетьмана Петра Сагайдачного, полковник, Львів, Україна.

Макєєв В. І. - канд. техн. наук, доцент, доцент військового відділення Сумського державного університету, Суми, Україна.

Іваник Є. Г. - канд. фіз.-мат. наук, старший науковий співробітник, доцент, старший науковий співробітник науководослідного відділу (навчально-тренувальних засобів та бойового екіпірування) Наукового центру Сухопутних військ Національної академії сухопутних військ імені гетьмана Петра Сагайдачного, Львів, Україна.

\section{АНОТАЦІЯ}

Актуальність. В рамках прийнятих гіпотез які спрощені запропоновано наближену схему розрахунку параметрів активної і пасивної ділянок траєкторії, яка дає змогу досліджувати властивості траєкторії руху існуючих, а також перспективних зразків реактивних та активно-реактивних снарядів. Об'єктом дослідження є модель розрахунку елементів траєкторії руху реактивних і активно-реактивних снарядів на основі нелінійної системи диференціальних рівнянь руху центра мас твердого тіла.

Мета роботи - запропонувати для практичного використання нову систему поправок в дальності і напрямку на відхилення умов польоту снарядів від табличних значень, заснованої на розрахунках елементів траєкторії руху снарядів в кінці активної ділянки траєкторії, що дозволяє значно підвищити точність підготовки установок для стрільби і як результат, ефективність ураження цілі.

Метод. Запропонований аналітичний метод дозволяє: визначати комплекс показників, що характеризують процес сходження реактивного снаряда 3 напрямної, і уточнення початкових умов необхідних для інтегрування системи рівнянь руху на активній ділянці траєкторії; розраховувати кінематичні елементи першої пасивної ділянки траєкторії для активнореактивних снарядів (мін), яка розглядається як самостійна траєкторія, що впливає на перебіг польоту снаряда на активній ділянці траєкторії. Розрахунок пасивної ділянки траєкторії для реактивних снарядів і другої пасивної ділянки для активнореактивних снарядів необхідні для отримання параметрів траєкторії в точці падіння (в околі цілі), що $є$ важливим для корегування вогню при наступному ураженні цілі реактивними (активно-реактивними) снарядами (мінами).

Результати. Розроблена методика розрахунку апробована при оцінюванні точності визначення елементів траєкторії руху реактивних снарядів.

Висновки. Проведені розрахунки на основі розробленої аналітичної методики підтверджують працездатність запропонованого математичного забезпечення і дозволяють рекомендувати його на практиці при вирішенні задач зовнішньої балістики з можливістю оптимізації траєкторії руху керованих і некерованих літальних об'єктів. Перспективи подальших досліджень полягають у створенні уточнених методів розрахунку тактико-технічних показників нових типів боєприпасів.

КЛЮЧОВІ СЛОВА: математичне моделювання руху балістичних тіл, тяга двигуна, секундна витрата палива, вага реактивного палива, час роботи двигуна, активна і пасивна ділянка траєкторії.

УДК 629.072 .19

\section{АНАЛИТИЧЕСКИЕ МЕТОДЫ РАССЧЕТА АКТИВНОГОИ ПАССИВНОГОУЧАСТКОВ ТРАЕКТОРИИ РЕАКТИВНЫХ И АКТИВНО-РЕАКТИВНЫХ СНАРЯДОВ}

Майстренко О. В. - д-р военных наук, начальник кафедры ракетных войск Национальной академии сухопутных войск имени гетмана Петра Сагайдачного, полковник, Львов, Украина.

Прокопенко В. В. - канд. техн. наук, заместитель начальника научно-исследовательского отдела (ракетных войск и артиллерии) Научного центра Сухопутных войск Национальной академии сухопутных войск имени гетмана Петра Сагайдачного, полковник, Львов, Украина.

Макеев В. I. - канд. техн. наук, доцент, доцент военного отделения Сумского государственного университета, Сумы, Украина.

Іваник Є. Г. - канд. физ.-мат. наук, старший научный сотрудник, доцент, старший научный сотрудник научноисследовательского отдела (учебно-тренировочных средств и боевого экипирования) Научного центра Сухопутных войск Национальной академии сухопутных войск имени гетмана Петра Сагайдачного, Львов, Украина.

\section{АННОТАЦИЯ}

Актуальность. В рамках принятых упрощающих гипотез предложена приближенная схема расчета параметров активного и пассивного участков траектории, позволяющая исследовать свойства траектории движения существующих, а также перспективных образцов реактивных и активно-реактивных снарядов. Объектом исследований является модель расчета элементов траектории движения реактивных и активно-реактивных снарядов на основе нелинейной системы дифференциальных уравнений движения центра масс твердого тела

Цель работы - предложить для практического использования новую систему поправок в дальности и направлении на отклонение условий полета снарядов от табличных значений, основанной на расчетах элементов траектории движения снарядов в конце активного участка траектории, что позволяет значительно повысить точность подготовки установок для стрельбы и в конечном итоге, - эффективность поражения цели.

Метод. Предложенный аналитический метод позволяет: определять комплекс показателей, характеризующих процесс схождения реактивного снаряда с направляющей, и уточнении начальных русловый необходимых для интегрирования системы уравнений движения на активном участке траектории; рассчитывать кинематические элементы первого пассивного участка траектории для активно-реактивных снарядов (мин), рассматриваемая как самостоятельная траектория, влияющая 
на процесс полета снаряда на активном участке траектории. Расчет пассивного участка траектории для реактивных снарядов и второго пассивного участка для активно-реактивных снарядов необходимы для получения параметров траектории в точке падения (в окрестности цели), имеющего важное значение для корректировки огня в последующем уничтожении цели реактивными (активно-реактивными) снарядами (минами).

Результаты. Разработанная методика расчета апробирована при оценивании точности определения элементов траектории движения реактивных снарядов.

Выводы. Проведенные расчеты на основе разработанной аналитической методики подтверждают работоспособность предлагаемого математического обеспечения и позволяют рекомендовать его для практического применения при решении задач внешней баллистики с возможностью оптимизации траектории движения управляемых и неуправляемых летательных объектов. Перспективы дальнейших исследований состоят в создании уточненных методов расчета тактико-технических показателей новых типов боеприпасов.

КЛЮЧЕВЫЕ СЛОВА: математическое моделирование движения баллистического тела, тяга двигателя, секундный расход топлива, вес реактивного топлива, время работы двигателя, активный и пассивный участок траектории.

\section{ЛІТЕРАТУРА / ЛИТЕРАТУРА}

1. Дмитриевский А. А. Внешняя баллистика / А. А. Дмитриевский, Л. Н. Лысенко. - М. : Машиностроение, 2005. $-607 \mathrm{c}$.

2. The flight of uncontrolled rockets / F. R. Gantmakher, L. M. Levin. - New York : Pergamum Press, 1964. $-379 \mathrm{p}$.

3. Макєєв В. І. Математична модель просторового руху літального апарату на твердому паливі в атмосфері / В. І. Макєєв // Вісник Сумського Державного університету. - 2008. - № 2. - С. 5-12.

4. Abbas L. K. Numerical investigations of aero elastic divergence parameter of unguided launch vehicles / L. K. Abbas, X. Rui // Space Research Journal. - 2011. - Issue 4(1). P. 1-11. DOI: 10.3923/srj.2011.1.11

5. Бурлов В. В. Баллистика ствольных систем / В. В. Бурлов, Л. Н. Лысенко. - М. : Машиностроение, 2006. -459 c.

6. Morote J. Flight Dynamics of Unguided Rockets with FreeRolling Wrap Around Tail Fins / J. Morote, G. Liaño // Journal of Spacecraft and Rockets. - 2006. - Issue 43(6). P. 1422-1423. DOI: $10.2514 / 1.22645$

7. Sun H. The control of asymmetric rolling missiles based on improved trajectory linearization control method / H. Sun, J. Yu, S. Zhang // Journal of Aerospace Technology and Management. - 2016. - Vol. 8, N 3. - P. 319-327. DOI: 10.5028/jactm.v813.617

8. Arutyunova N. K. Models and methods for three external ballistics inverse problems / N. K. Arutyunova, A. M. Dulliev, V. I. Zabotin // Bulletin of the South Ural State University. Ser. Mathematical Modelling, Programming \& Computer Software (Bulletin SUSU MMCS). 2017. - Vol. 10, No. 4. - P. 78-91. DOI: $10.14529 / \mathrm{mmp} 170408$

9. Sahu J. Unsteady computational fluid dynamics modeling of free-flight projectile aerodynamics / J. Sahu // WIT
Transactions on Modelling and Simulation. - 2007. Vol. 45. - P. 3-12. DOI: 10.2495/CBAL070011

10. Kokes J. Generating an aerodynamic model for projectile flight simulation using unsteady time accurate computational fluid dynamic results / J. Kokes, M. Costello, J. Sahu // WIT Transactions on Modelling and Simulation. - 2007. Vol. 45. - P. 31-54. DOI: 10.2495/CBAL070041

11. McCoy R. L. Modern Exterior Ballistics: The Launch and Flight Dynamics of Symmetric Projectiles / R. L. McCoy. Atglen, PA: Schiffer Publishing Ltd., 2012. - 328 p.

12. Исследование влияния параметров работы реактивного двигателя на дальность и кучность стрельбы реактивных снарядов / [В. И. Макеев, В. И. Грабчак, П. Е. Трофименко, Ю. И. Пушкарев] // Системы обработки информации. - 2008. - Выпуск 6(73). - С. 77-81.

13. Обоснование рациональной системы поправок при стрельбе активно-реактивными снарядами (минами) / [Грабчак В. И., Макеев В. И., Трофименко П. Е., Пушкарев Ю. И.] // Артиллерийское и стрелковое вооружение. - 2009. - № 4. - C. 3-9.

14. Celis R. D. Guidance and control for high dynamic rotating artillery rockets / R. D Celis, L. Cadarso, J. Sánchez // Aerospace Science and Technology. - 2017. - Vol. 64. P. 204-212. DOI:10.1016/j.ast. 2017.01.026

15. A review of flight dynamics simulation model of missiles / D. N. Gkritzapis, G. Kaimakamis, K. Siassiakos, M. Chalikias $/ / 2^{\text {nd }}$ European Computing Conference (ECC'08), Malta, September 11-13, 2008. P. 257-261.

16. Lahti J. Control of exterior ballistic properties of spinstabilized bullet by optimizing internal mass distribution / J. Lahti, T. Sailaranta, M. Harju, K. Virtanen // Defence Technology. - 2019. - Vol. 15. - P. 38-50. DOI: 10.1016/j.dt.2018.10.003 